\title{
DISTRIBUTION OF THE GLOBIN GENE IN ACTIVE AND INACTIVE CHROMATIN FRACTIONS FROM FRIEND ERYTHROLEUKEMIA CELLS
}

\author{
ALAN F. LAU, ${ }^{1}{ }^{*}$ RAYMOND W. RUDDON, ${ }^{1}{ }^{* *}$ MARC S. COLLETT ${ }^{2}$ and \\ ANTHONY J. FARAS ${ }^{2}$ \\ 'Department of Pharmacology, University of Michigan, Medical School, Ann Arbor, MI 48109, \\ and 'Department of Microbiology, University of Minnesota, Minneapolis, MN 55455, USA
}

\begin{abstract}
SUMMARY
Stimulation of the $\mathrm{T} 3 \mathrm{C} 12$ clone of Friend erythroleukemia cells with $1.2 \%$ dimethyl sulfoxide (DMSO) results in progressive increase in the concentration of globin mRNA sequences in the total cellular RNA of treated cells, as measured by nucleic acid hybridization employing a globin cDNA probe. The greatest increment in the content of globin RNA occurs between 30 and $40 \mathrm{~h}$ after addition of DMSO. Globin cDNA was also used to measure the concentration of globin-specific sequences in the DNA and RNA of transcriptionally active and inactive chromatin fractions prepared from these cells by the DNase II $-\mathrm{MgCl}_{2}$ procedure of Gottesfeld et al. [16]. Essentially equal concentrations of globin sequences are present in the DNA isolated from active and inactive chromatin fractions of cells grown in the presence of $1.2 \%$ DMSO for $50 \mathrm{~h}$ (the time of initiation of hemoglobin synthesis). Furthermore, there are no significant differences in the globin gene concentrations between the active chromatin fractions from DMSO-treated and control cultures at either 50 or $120 \mathrm{~h}$ after initiation of DMSO treatment. However, chromatin-associated RNA isolated from the active chromatin of cells synthesizing maximum amounts of hemoglobin $(120 \mathrm{~h})$ contains a higher concentration of globin sequences than RNA from the active chromatin of control cells. Chromatin fractions from untreated cells also contain a significant amount of RNA which hybridizes to the globin cDNA probe. These observations suggest that both transcriptional and post-transcriptional control mechanisms are involved in hemoglobin gene expression in $\mathrm{T} 3 \mathrm{C} 12$ erythroleukemia cells.
\end{abstract}

Only a minor portion of the total nuclear DNA of differentiated cells in a mammalian organism is transcribed [1]. Restriction of transcription of nuclear DNA has been implicated as a major mechanism by which eukaryotic cells regulate gene expression during development [2-5]. In order to further elucidate possible transcriptional

\footnotetext{
* Present address: Department of Microbiology, University of Minnesota, Minneapolis, MN 55455, USA. ** Present address: Biological Markers Laboratory Frederick Cancer Research Center, Frederick, MD 21701, USA.
}

To whom offprint requests should be addressed. mechanisms of specific gene expression, several methods have been developed for the preparation of chromatin fractions actively engaged in transcription. Transcriptional activities of isolated chromatin fractions are frequently defined by (1) the presence of nascent RNA chains [6-9]; (2) endogenous RNA polymerase activity $[7,10$, 11]; (3) the preferential binding to [12] or transcription of $[7-9,12,13]$ chromatin by $E$. coli RNA polymerase. The studies of Howk et al. [14], utilizing the Moloney type "C" proviral DNA sequence in infected 
$3 \mathrm{~T} 3$ cells, and Rickwood et al. [15], using the globin gene in the 707 clone of murine erythroleukemia cells, have examined the possibility of enrichment of specific gene sequences in "active" chromatin isolated by three different chromatin fractionation schemes. In both reports, the results indicated that although the genes under investigation were transcribed in vivo, they were not preferentially segregated into the isolated "active" chromatin fractions. Instead, nearly equal concentrations of the active gene sequences were found in "active" and "inactive" chromatin.

The fractionation scheme devised by Gottesfeld et al. [16, 17] has provided an additional way to prepare transcriptionally active chromatin fractions. In this method, chromatin is first sheared by limited digestion with DNase II. Inactive chromatin is separated by centrifugation and precipitation with $2 \mathrm{mM} \mathrm{MgCl}$. The soluble active chromatin fraction has been shown to consist of tissue-specific subsets of middle and non-repetitive DNA sequences $[16,17]$. In addition, the non-repetitive class of DNA from the putative active fraction appears to be enriched in sequences coding for cellular RNA [16]. After extensive DNase II digestion, both transcriptionally active and inactive chromatin contain "subunits" of nucleoprotein. The nuclease resistant structures of inactive chromatin are DNA-histone complexes resembling $\nu$ bodies; however, those from active chromatin are complexes of DNA, RNA, histone, and nonhistone proteins [18].

A preferential digestion of active chromatin segments has also been observed with DNase I. Weintraub \& Groudine [19] have shown that the active globin gene of erythrocyte nuclei, but not the inactive ovalbumin gene, is preferentially digested by DNase I. Similar results have been obtained for the transcriptionally active ovalbumin gene from chick oviduct nuclei [20].

In this study we have employed the $\mathrm{T} 3 \mathrm{C} 12$ clone of murine erythroleukemia cells, which accumulate globin mRNA after stimulation by dimethyl sulfoxide (DMSO), to determine whether changes in the content of globin gene sequences could be detected in the "active" chromatin fraction of DMSO-treated cells.

\section{MATERIALS AND METHODS}

\section{Growth of cells}

The $\mathrm{T} 3 \mathrm{C} 12$ clone of murine erythroleukemia cells, originally isolated by Ikawa et al. [21], was obtained from the National Institutes of Health through the courtesy of Dr Philip Leder. Cells were grown and stimulated as previously described [22]. Synthesis of hemoglobin in the cultures was determined by benzidine staining [23]. Addition of $1.2 \%$ DMSO to cultures of $\mathrm{T} 3 \mathrm{C} 12$ cells resulted in the accumulation of hemoglobin beginning $50 \mathrm{~h}$ after exposure to the inducer. By $120 \mathrm{~h}$ greater than $90 \%$ of the treated cells contained hemoglobin, but only $1-2 \%$ of the untreated control cells were benzidine positive.

\section{Preparation of nucleic acids from chromatin fractions}

Chromatin was prepared from control and treated cells by a modification [22] of the procedure of Huang \& Huang [24]. Purified chromatin was fractionated as described by Gottesfeld et al. [16]. Chromatin pellets $P_{1}$ and $P_{2}$ represented inactive fractions, whereas the $\mathrm{S}_{2}$ supernatant contained actively transcribed chromatin segments $[16,22]$.

Total nucleic acids were prepared from these chromatin fractions by the following procedures. Chromatin pellets were resuspended in STE buffer $(0.02 \mathrm{M}$ Tris-HCl (pH 7.4), 0.1 M NaCl, 0.001 M EDTA). Sodium dodecyl sulfate (SDS) and self-digested Pronase (nuclease-free, Calbiochem) were added to attain $0.5 \%$ and $500 \mu \mathrm{g} / \mu \mathrm{l}$, respectively. After a $30 \mathrm{~min}$ incubation at $37^{\circ} \mathrm{C}$ the samples were extracted three times with equal volumes of STE-saturated phenol. The final aqueous phases were precipitated overnight at $-20^{\circ} \mathrm{C}$ with 2 vol of ethanol. DNA was prepared from total nucleic acid preparations of cells grown for 50 or $120 \mathrm{~h}$ with or without DMSO by adjusting the samples to $0.3 \mathrm{~N} \mathrm{NaOH}$ and heating at $100^{\circ} \mathrm{C}$ for 30 min. This procedure also shears the DNA to $200-300$ nucleotides in length [25]. After neutralization the DNA was recovered by ethanol precipitation. 
Chromatin-associated RNA was also isolated from the various chromatin fractions of cells grown for 120 $h$. In this case, a portion of the total nucleic acid preparation was redissolved in $0.02 \mathrm{M}$ Tris- $\mathrm{HCl}(\mathrm{pH}$ 7.4), $0.01 \mathrm{M} \mathrm{MgCl}_{2}$ to a concentration $\leqslant 1 \mathrm{mg} / \mathrm{ml}$. DNA was digested with $20 \mu \mathrm{g} / \mathrm{ml}$ of RNase-free DNase I [26] at room temperature for $2 \mathrm{~h}$ followed by phenol extraction and ethanol precipitation. This DNase I digestion process was repeated once to insure complete removal of DNA.

\section{Isolation of total cellular RNA}

In order to examine the synthesis of globin mRNA, control and $1.2 \%$ DMSO-treated cells were grown for $20,30,40,60$, and $90 \mathrm{~h}$ as described [22]. Total cellular RNA was isolated from these cells by procedures described above: Pronase digestion, phenol extraction, DNase I digestion, and re-extraction with phenol.

\section{Globin cDNA synthesis}

Globin mRNA was isolated from mouse reticulocyte polysomal RNA by column chromatography on oligo(dT)-cellulose [27] followed by sucrose gradient centrifugation. The $9 \mathrm{~S}$ globin mRNA was homogenous on $2 \%$ acrylamide, $0.5 \%$ agarose gels [28] and coded only for $\alpha$ - and $\beta$-globin peptide chains in a wheat germ cell-free protein synthesizing system [29].

DNA complementary to mouse globin mRNA (globin CDNA) was synthesized essentially as described by Sullivan et al. [30]. The $0.5 \mathrm{ml}$ reaction mixture consisted of the following: $0.06 \mathrm{M}$ Tris- $\mathrm{HCl}(\mathrm{pH} \mathrm{8.1}$ ), $0.008 \mathrm{M} \mathrm{MgCl}_{2}, 1 \times 10^{-4} \mathrm{M}$ each of dCTP and dTTP, $500 \mu \mathrm{Ci} / \mathrm{ml}$ each of $\left[{ }^{3} \mathrm{H}\right] \mathrm{dGTP}\left(3.6 \times 10^{-5} \mathrm{M}\right)$ and $\left[{ }^{3} \mathrm{H}\right] \mathrm{dATP}\left(4.2 \times 10^{-5} \mathrm{M}\right), 0.028 \mathrm{M} \beta$-mercaptoethanol, $1 \mu \mathrm{g} / \mathrm{ml}$ oligo(dT) $)_{12-18}, 100 \mu \mathrm{g} / \mathrm{ml}$ actinomycin $\mathrm{D}$, $6.7 \mu \mathrm{g} / \mathrm{ml}$ mouse globin $\mathrm{mRNA}$, and $5 \mathrm{U} / \mathrm{ml}$ avian myeloblastosis virus reverse transcriptase $(\mathrm{Dr} \mathrm{J}, \mathrm{W}$. Beard, Life Sciences, Inc.). Bentonite $(32 \mu \mathrm{g} / \mathrm{ml})$ was also added to inhibit any residual RNase activity present in the reverse transcriptase preparations [31].

After a $16 \mathrm{~h}$ incubation at $37^{\circ} \mathrm{C}$, the sample was digested with Pronase, phenol-extracted, and precipitated with ethanol as described above. The de-proteinized nucleic acids were dissolved in $100 \mu \mathrm{l}$ of 0.02 $\mathrm{M}$ Tris- $\mathrm{HCl}$ (pH 7.4), $0.01 \mathrm{M}$ EDTA and digested with RNase $(50 \mu \mathrm{g} / \mathrm{ml})$ at $37^{\circ} \mathrm{C}$ for $1 \mathrm{~h}$. The DNA was then phenol-extracted and ethanol-precipitated overnight. Single-strand DNA was separated from duplex DNA on hydroxyapatite [32], desalted by Sephadex G-50 chromatography, and precipitated in ethanol. A total of $1.4 \times 10^{6} \mathrm{cpm}$ of single-stranded DNA with a specific activity of $16000 \mathrm{cpm} / \mathrm{ng}$ was obtained. Only $7 \%$ of the DNA prepared in this manner was resistant to digestion by the single-strand-specific $S_{1}$ nuclease, and it was $4-6 \mathrm{~s}$ in size on alkaline sucrose gradients. Results of hybridization of this cDNA probe to mouse globin mRNA are presented in fig. 1. Hybrid formation was first detected at a $C_{r} t$ value of approx. $5 \times 10^{-4}$ and was essentially completed at a $C_{r} t$ of $1 \times 10^{-2}$. Therefore, it is likely that the cDNA preparation consists of only two classes of molecules ( $\alpha$ - and $\beta$-globin cDNA) which are present in equal amounts and reflect the $1: 1$ ratio of $\alpha$ - and $\beta$-globin mRNA in mouse reticulocyte polysomes [33]. The $C_{r} t_{\frac{1}{2}}$ (value at which $50 \%$ hybridization is achieved) of $2 \times 10^{-3}$ is nearly identical with the value of $1.7 \times 10^{-3}$ obtained by Gielen et al. [34] for the hybridization of rabbit globin mRNA to its cDNA product.

\section{Nucleic acid hybridization}

All globin CDNA:RNA hybridizations were performed in $50 \mu$ l volumes containing $0.6 \mathrm{M} \mathrm{NaCl}, 0.04$ M Tris- $\mathrm{HCl}$ (pH 7.4), 0.002 M EDTA, approx. 1000 cpm of globin cDNA, and variable amounts of sample RNA diluted with $2 \mathrm{mg} / \mathrm{ml}$ yeast RNA. The yeast RNA was employed to reduce the effects of residual ribonuclease activity. Mixtures were overlaid with mincral oil and incubated at $68^{\circ} \mathrm{C}$ for $24 \mathrm{~h}$. Globin cDNA : chromatin DNA hybridizations were conducted in $30 \mu \mathrm{l}$ volumes which contained: $0.02 \mathrm{M}$ Tris$\mathrm{HCl}$ (pH 7.4), 0.01 M EDTA, $0.6 \mathrm{M} \mathrm{NaCl}, 2600 \mathrm{cpm}$ globin cDNA, and variable amounts of test DNA. Samples were overlaid with mineral oil and incubated at $68^{\circ} \mathrm{C}$ for 50 or $100 \mathrm{~h}$. The extent of hybridization of each sample was determined by single-strandspecific $S_{1}$ nuclease [35] prepared from Sanzyme-R (Calbiochem) by chromatography on DEAE-cellulose [36].

\section{RESULTS}

\section{Accumulation of globin mRNA in $\mathrm{T} 3 \mathrm{C12}$} erythroleukemia cells treated with DMSO Accumulation of globin mRNA in DMSOtreated $\mathrm{T} 3 \mathrm{C} 12$ cells was measured by nucleic acid hybridization between a DNA probe complementary to globin mRNA (cDNA) and total cellular RNA isolated from cells grown for varying periods of time. The data in fig. 2 indicate a timedependent increase in globin RNA concentration, as evidenced by the progressive decrease in $C_{r} t_{t}$ values of the RNA preparations from treated cells. The largest increment in globin mRNA concentration (10fold) was seen between $30-40 \mathrm{~h}$ after stimulation with DMSO. This increase occurred immediately prior to hemogiobin synthesis in these cells. Unstimulated cell samples, on the other hand, did not show progressive increase in concentration of globin mRNA (data not shown). 


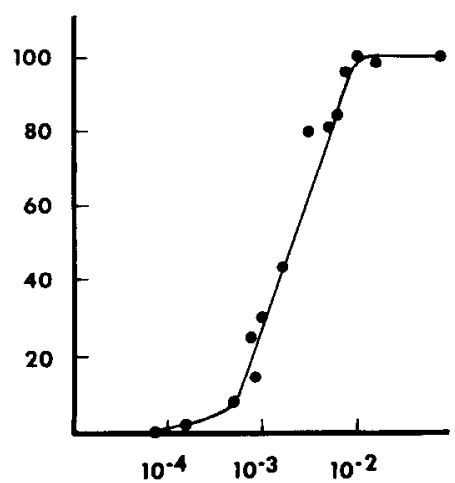

Fig. 1. Abscissa: $C_{r} t$ values; ordinate: \% hybridization. $C_{r} t_{1}=2.00 \times 10^{-3}$.

Hybridization of globin cDNA to mouse globin mRNA. Mouse globin mRNA was isolated as described in the "Materials and Methods". Hybridizations were performed in $50 \mu \mathrm{l}$ with $0.6 \mathrm{M} \mathrm{NaCl}$, $1000 \mathrm{cpm}$ of globin cDNA, and variable amounts of globin mRNA to achieve the desired $C_{r} t$ values. Samples were allowed to anneal at $68^{\circ} \mathrm{C}$ for $24 \mathrm{~h}$. Hybrid formation was determined using single-strandspecific $S_{1}$ nuclease. Data were corrected for the $7 \%$ self-annealing of the globin cDNA.

\section{Analysis of "active" and "inactive"} chromatin fractions for the presence of the globin gene

Transcriptional activities of chromatin fractions isolated by the DNase II $-\mathrm{MgCl}_{2}$ techniques of Gottesfeld et al. [16] from $\mathrm{T} 3 \mathrm{C} 12$ cells were estimated by the incorporation of radioactive uridine into rapidly-labeled chromatin-associated RNA [22]. These results indicated that the active chromatin fractions (S2) of both control and treated cells had specific activities $\left(\left[{ }^{3} \mathrm{H}\right]\right.$ uridine $\mathrm{cpm} / \mu \mathrm{g}$ DNA) 7-14-fold greater than the inactive $\left(\mathrm{P}_{1}\right.$ and $\left.\mathrm{P}_{2}\right)$ fractions. In addition, approx. $50 \%$ of the total incorporated uridine counts were found in the active fraction, which contained only $5 \%$ of the total chromatin DNA [22].

The concentration of globin gene sequences was examined in actively- and inactively-transcribed chromatin fractions from control and DMSO-induced cells grown for $50 \mathrm{~h}$ (the apparent time of onset of hemoglobin synthesis) and $120 \mathrm{~h}$ (the time of maximum hemoglobin synthesis). The active and inactive chromatin from cells grown without DMSO for $50 \mathrm{~h}$ appeared to contain nearly identical concentrations of the globin gene. As shown in fig. 3, the $C_{0} t_{i}$ values for the $P_{1}$ (inactive) and $S_{2}$ (active) DNA were $9 \times 10^{3}$ and $11 \times$ $10^{3}$, respectively. Similar data were obtained for cells grown $50 \mathrm{~h}$ in the presence of DMSO. Furthermore, no increase (compared with control) in the globin gene concentration of the $S_{2}$ fraction from treated cells was evident. Chromatin fractions isolated from cells grown for $120 \mathrm{~h}$ provided essentially the same results (data not shown), in that the globin gene concentrations of the control and treated active fractions were virtually identical with apparent $C_{o} t_{t}$ values of $2.3 \times 10^{4}$ and $3.5 \times 10^{4}$, respectively.

\section{Globin-specific nucleotide sequences in chromatin-associated RNA}

RNA associated with the chromatin fractions of control and treated cells grown for

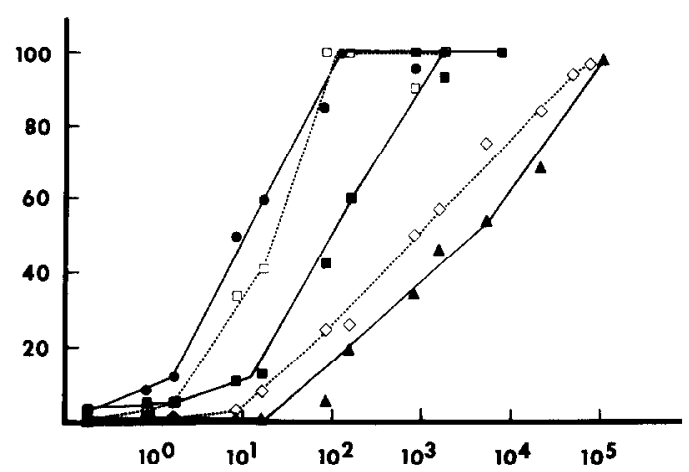

Fig. 2. Abscissa: $C_{r} t$ values; ordinate: $\%$ hybridization.

Hybridization of globin cDNA to total cellular RNA from 1.2\% DMSO-treated cells. Cells were stimulated for $\Delta-\Delta, 20 \mathrm{~h} ; \diamond \ldots \diamond, 30 \mathrm{~h} ; \square-\mathbf{m}, 40 \mathrm{~h} ; \square \ldots \square$, $60 \mathrm{~h}$; and $-90 \mathrm{~h}$. Total cellular RNA was isolated as described in the "Materials and Methods". Hybridizations were performed as indicated in fig. 1. 


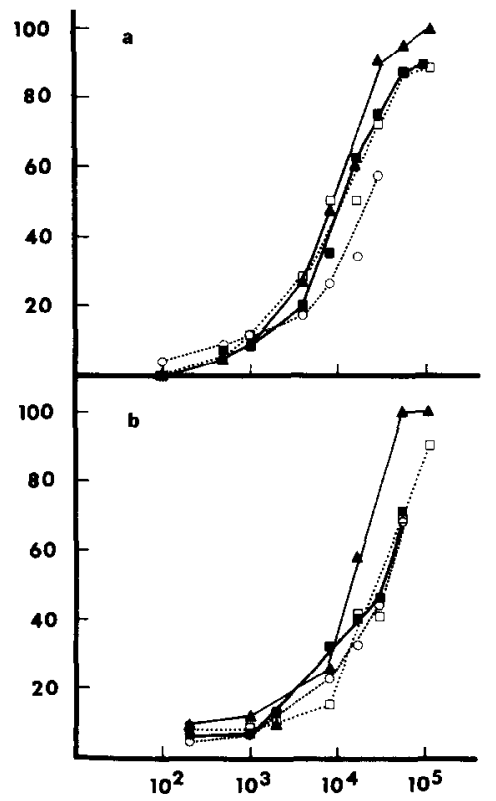

Fig. 3. Abscissa: $C_{0} t$ values; ordinate: \% hybridization.

Hybridization of globin CDNA to DNA of chromatin fractions isolated from control and $1.2 \%$ DMSOtreated T3C12 cells. DNA of chromatin fractions isolated from $(a)$ control or $(b)$ treated cells grown for 50 h. $\mathrm{O}--\mathrm{O}$, Unfractionated chromatin; $\boldsymbol{\Lambda}-\mathbf{A}, \mathrm{P}_{\mathbf{1}}$; $\square \cdots \square, P_{2}$; and $\square, S_{2}$. Hybridizations were performed as described in fig. 1 in $30 \mu l$ with $2600 \mathrm{cpm}$ of globin cDNA and varying amounts of DNA. Samples were allowed to anneal at $68^{\circ} \mathrm{C}$ for 50 or $100 \mathrm{~h}$.

$120 \mathrm{~h}$ was examined for its concentration of globin RNA sequences at $2 C_{r} t$ values. The data in table 1 indicate that all fractions contained material that was complementary to the cDNA probe. The unfractionated, $\mathrm{P}_{1}$, and $S_{2}$ chromatin of the control group contained globin sequences which were detectable at a $C_{r} t$ of $7.5 \times 10^{2}$. RNA from the control $\mathrm{P}_{2}$ fraction had the lowest concentration of globin sequences. The hybridization values for all four treated chromatin fractions were greater than the controls at both $C_{r} t$ values. The treated $\mathrm{S}_{2}$ fraction contained the greatest concentration of globin RNA sequences. In order to eliminate the possibility that the hybridization observed with the RNA isolated from
Table 1. Hybridization of globin cDNA to chromatin-associated RNA from control and $1.2 \%$ DMSO-treated $T 3 C 12$ cells

RNA was extracted from chromatin fractions of cells grown for $120 \mathrm{~h}$ after 2 cycles of DNase I digestion as described under "Materials and Methods". RNA was hybridized to globin cDNA as outlined in fig. 1. Each hybridization value represents the mean of two independent determinations of the same RNA preparation (average variation from the mean $<10 \%$ ). UC represents unfractionated chromatin, $P_{1}$ and $P_{2}$ inactive chromatin, and $S_{2}$ active chromatin

\begin{tabular}{lll}
\hline & \multicolumn{2}{l}{$\%$ Hybridization } \\
\cline { 2 - 3 } Fraction & $C_{r} t=7.5 \times 10^{1}$ & $C_{r} t=7.5 \times 10^{2}$ \\
\hline Control & & \\
UC & 7.5 & 43.2 \\
$\mathrm{P}_{1}$ & 9.7 & 50.8 \\
$\mathbf{P}_{2}$ & 4.3 & 12.3 \\
$\mathrm{~S}_{2}$ & 2.6 & 40.8 \\
Treated & & \\
UC & 29.4 & 75.8 \\
$\mathbf{P}_{1}$ & 15.8 & 61.0 \\
$\mathbf{P}_{2}$ & 26.0 & 67.7 \\
$\mathbf{S}_{2}$ & 48.4 & 83.3 \\
\hline
\end{tabular}

treated cell chromatin was due to cytoplasmic globin mRNA, potential contamination of treated cell chromatin fractions was estimated by the addition of $\left[{ }^{3} \mathrm{H}\right]$ uridine-labeled $\mathrm{T} 3 \mathrm{C} 12$ cytoplasmic RNA to the total cell homogenate of a DMSOinduced culture. Chromatin fractions were isolated, and the radioactivity associated with each fraction was determined. Less than $0.27-0.33 \%$ of the recovered radioactivity was associated with the DMSOtreated cell chromatin fractions in these experiments. The expected hybridization due to possible contaminating cytoplasmic globin mRNA was calculated using the following parameters: (1) the \% contamination by ${ }^{3} \mathrm{H}$-labeled cytoplasmic RNA $(0.27-$ $0.33 \%$ ); (2) specific activity of the labeled cytoplasmic RNA; (3) the fraction of the cytoplasmic RNA which is globin mRNA (0.02\% from Ross et al., [5]); and (4) hybridization values obtained from fig. 1 . For 
the treated $\mathrm{S}_{2}$ chromatin RNA, for example, it was calculated that the extent of contamination $(0.27 \%$ of the recovered radioactivity) could only account for about $2 \%$ of the observed hybridization at a $C_{r} t$ value of $7.5 \times 10^{2}$ (table 1). A 10-fold underestimation of the concentration of cytoplasmic globin mRNA would increase the $2 \%$ hybridization value to $20 \%$, still less than $1 / 4$ of the actual observed value.

\section{DISCUSSION}

The chromatin fractionation procedure of Gottesfeld et al. [16] was utilized to study a cell line in which transcriptional control appears to be of primary importance in the accumulation of globin mRNA. One of the purposes was to determine if a detectable shift occurs in the structural configuration of the globin gene in erythroleukemia cells induced to synthesize hemoglobin by the addition of DMSO. From our results this does not appear to be the case. Examination of the active $\left(S_{2}\right)$ and inactive $\left(P_{1}\right.$ and $\mathrm{P}_{2}$ ) chromatin fractions from control and treated $\mathrm{T} 3 \mathrm{C} 12$ cells indicates no major differences in the concentration of the globin gene (fig. 3).

The reasons for the lack of a distinct segregation of globin gene sequences between transcriptionally active and inactive chromatin may relate to one or more of the following points. (1) The apparent synthesis of globin RNA in unstimulated T3C12 cells (table 1), suggests the existence of posttranscriptional control mechanisms. The globin gene appears to be transcribed in control cells without translation of the globin mRNA. Under such circumstances, the globin gene concentration in the active chromatin of DMSO-stimulated cells might be expected to be similar to that in the controls. Rickwood et al. [15] also report no segregation of the globin gene in the active chrumatin fraction (isolated on metrizamide gradients) in the 707 clone of crythroleukemia cells, in which posttranscriptional control mechanisms are known to be operative [37, 38]. (2) Weintraub \& Groudine [19] have reported that the globin gene in mature chick erythrocytes is in a conformation which is susceptible to DNase I digestion. Interestingly, this susceptibility is not necessarily due to the actual transcription of the gene since the globin gene in mature erythrocytes, which are not transcribing globin mRNA, is still digested by DNase I. It is conceivable that a configuration which is sensitive to DNase I is established for those genes normally transcribed during the development of a particular cell type irrespective of whether they are actually being transcribed at the time. This may be the case for $\mathrm{T} 3 \mathrm{C} 12$ cells which appear to be arrested at some early stage in erythroid differentiation. It is possible that at this stage a DNase sensitive configuration already exists for the globin genes which are only minimally transcribed until the proper stimulus (e.g. DMSO) is encountered. DNase II used in this chromatin fractionation procedure may recognize this configuration to an equivalent extent in both control and treated cells, resulting in equal concentrations of the globin gene in the active fraction from both types of cells. Finally, lack of a differential distribution of the globin gene between the active and inactive chromatin of control and treated cells may also reflect an incomplete separation of activelytranscribed DNA sequences from the inactive chromatin fraction by the DNase II method.

The globin cDNA probe was also used to examine the concentration of globin RNA sequences in total cellular RNA and in 
chromatin-associated RNA from DMSOstimulated cells. It was found that the globin RNA concentration increases as early as $30 \mathrm{~h}$ after DMSO addition (fig. 2); however, the largest increment occurs between 30 and $40 \mathrm{~h}$, well before hemoglobin is first detected $(50-60 \mathrm{~h})$ by the benzidine stain. Comparison of the 20 and $90 \mathrm{~h} C_{r} t_{3}$ values indicates that there is an overall 400 -fold increase $\left(4 \times 10^{3} / 1 \times 10^{1}\right)$ in the concentration of globin RNA in these cells. Using the mouse globin mRNA as a standard (fig. 1), it is calculated that the total RNA of cells stimulated for $90 \mathrm{~h}$ contains $0.02 \%$ globin sequences. This is in accord with the value obtained by Ross et al. [5] for DMSO-treated $\mathrm{T} 3 \mathrm{C} 12$ cells. The concentration of globin mRNA in the mouse reticulocyte is $2.8 \%$ of the total cellular RNA [5]. Thus, the reticulocyte contains over 100 times the concentration of globin mRNA present in the $90 \mathrm{~h}$-induced T3C12 cell. This is not surprising since the $\mathrm{T} 3 \mathrm{C} 12$ cell would be expected to contain a wider variety of mRNA than does the reticulocyte.

Previously reported results indicate that the active $\left(S_{2}\right)$ chromatin fractions from both control and treated $\mathrm{T} 3 \mathrm{C} 12$ cells contain the highest specific activities of rapidlylabeled nuclear RNA [22]. Using the globin cDNA probe to measure the concentration of globin RNA sequences in chromatinassociated RNA (table 1), it was found that the treated cell chromatin fractions contain higher concentrations of globin RNA and that the active $\left(S_{2}\right)$ fraction from treated cells has the greatest concentration. Berkowitz \& Doty [9] have also reported that active chromatin of chicken reticulocytes, obtained by sucrose gradient centrifugation, contained approx. 5-fold more globin RNA than the inactive fraction.

In the case of the $\mathrm{T} 3 \mathrm{C} 12$ clone, it has been thought that the induction of globin RNA and hemoglobin synthesis was due primarily to a change in gene transcription $[5,39,40]$. Thus, the hybridization observed between globin cDNA and RNA obtained from control cell chromatin fractions was unexpected. Although unstimulated cultures exhibit a low basal level of differentiation (1-2\% of the cells are benzidine-positive at $120 \mathrm{~h}$ ), it is unlikely that this would account for the $40-50 \%$ hybridization observed at a $C_{r} t$ of $7.5 \times 10^{2}$. This result implies a role for post-transcriptional mechanisms in the control of globin gene expression in $\mathrm{T} 3 \mathrm{C} 12$ cells, as has been suggested by Paul and his colleagues for the 707 clone of erythroleukemia cells $[37,38]$. Post-transcriptional control mechanisms may be exerted during nuclear processing, transport to the cytoplasm, or translation of mRNA. A rigorous examination of the concentration of globin RNA in chromatin, nuclear, polysomal, and "soluble" fractions of these cells is necessary to settle this issue.

In summary, the induction of hemoglobin synthesis in $\mathrm{T} 3 \mathrm{C} 12$ erythroleukemia cells most likely results from changes in both transcriptional and post-transcriptional events which do not appear to coincide with a change in the structural arrangement of the globin gene as detected by DNase II sensitivity.

A preliminary report of this data was presented at the annual meeting of the American Association for Cancer Research, May 4-8, 1976.

Dual-isotope data were calculated with the help of the University of Michigan Medical School Fund for computing. This work was supported by the NIH grant CA-12765 and by the University of Michigan, Department of Pharmacology Training Grant NIGMS 198-18.

\section{REFERENCES}

1. Davidson, E H \& Britten, R J, Cancer res 34 (1974) 2034. 
2. Harris, S E, Rosen, J M, Means, A R \& O'Malley, B W, Biochemistry 14 (1975) 2072.

3. O'Malley, B W, Rosenfeld, G C, Comstock, J P \& Means, A R, Nature new biol 240 (1972) 45.

4. Terada, M, Cantor, L, Metafora, S, Rifkind, R A, Bank, A \& Marks, P A, Proc natl acad sci US 69 (1972) 3575.

5. Ross, J, Gielen, J, Packman, S, Ikawa, Y \& Leder, P, J mol biol 87 (1974) 697.

6. Frenster, J H, Allfrey, V G \& Mirsky, A E, Proc natl acad sci US 50 (1963) 1026.

7. Anderson, K M, Chance, H \& Kadohama, N, Exp cell res 94 (1975) 176.

8. Janowski, M, Nasser, D S \& McCarthy, B J, Karolinska Symposia on research methods in reproductive endocrinology, 5th Symposium (ed E Diczfalusy) p. 112. Karolinska Institutet, Stockholm (1972).

9. Berkowitz, E M \& Doty, P, Proc natl acad sci US 72 (1975) 3328

10. Pederson, T \& Bhorjee, J S, Biochemistry 14 (1975) 3238.

11. Marushige, $\mathrm{K} \&$ Bonner, J, Proc natl acad sci US 68 (1971) 2941.

12. Simpson, R T, Proc natl acad sci US 71 (1974) 2740.

13. Magee, B B, Paoletti, J \& Magee, P T, Proc natl acad sci US 72 (1975) 4830.

14. Howk, R S, Anisowicz, A, Silverman, A Y, Parks, W P \& Scolnick, E M, Cell 4 (1975) 321

15. Rickwood, D, Hell, A, Malcolm, S, Birnie, G D, MacGillivray, A J \& Paul, J, Biochim biophys acta 353 (1974) 353.

16. Gottesfeld, J M, Garrard, W T, Bagi, G, Wilson, R F \& Bonner, J, Proc natl acad sci US 71 (1974) 2193.

17. Gottesfeld, J M, Bagi, G, Berg, B \& Bonner, J, Biochemistry 15 (1976) 2472.

18. Gottesfeld, J M, Murphy, R F \& Bonner, J, Proc natl acad sci US 72 (1975) 4404.

19. Weintraub, H \& Groudine, M, Science 193 (1976) 848.

20. Garel, A \& Axel, R, Proc natl acad sci US 73 (1976) 3966.

21. Ikawa, Y, Ross, J, Leder, P, Gielen, J, Packman, S, Ebert, P, Hayaski, K \& Sugano, H, Differentiation and control of malignancy of tumor cells (ed W Nakahara, T Ono, T Sugimura \& H Sugano) p. 515. University Park Press, Baltimore, Md (1974).
22. Lau, A F \& Ruddon, R W, Exp cell res 107 (1977) 35

23. Orkin, S H, Harosi, F I \& Leder, P, Proc natl acad sci US 72 (1975) 98.

24. Huang, R-C C \& Huang, P C, J mol biol 39 (1969) 365 .

25. Tibbets, C, Johansson, K \& Philipson, L, J virol 12 (1973) 218.

26. Zimmerman, S B \& Sandeen, G, Anal biochem 14 (1966) 269.

27. Aviv, H \& Leder, P, Proc natl acad sci US 69 (1972) 1408.

28. Peacock, A C \& Dingman, C W, Biochemistry 7 (1969) 668

29. Marcu, K \& Dudock, B, Nucleic acids res 1 (1974) 1385.

30. Sullivan, D, Palacios, R, Stavnezer, J, Taylor, J M, Faras, A J, Kiely, M L, Summer, N M, Bishop, J M \& Schimke, R T, J biol chem 248 (1973) 7530.

31. Collett, M S \& Faras, A J, Biochem biophys res commun 67 (1975) 946.

32. Fanshier, L, Garapin, A C, McDonnell, J, Faras, A J, Levinson, W \& Bishop, J M, J virol 7 (197I) 77.

33. Morrison, M R, Brinkley, S A, Gorski, J \& Lingrel, J B, J biol chem 249 (1974) 5290.

34. Gielen, J, Aviv, H \& Leder, P, Arch biochem biophys 163 (1974) 146.

35. Leong, J-A, Garapin, A C, Jackson, N, Fanshier, L, Levinson, W \& Bishop, J M, J virol 9 (1972) 891.

36. Sutton, W D, Biochim biophys acta 240 (1971) 522.

37. Harrison, P R, Gilmour, R S, Affara, N A, Conkie, N \& Paul, J, Cell differ 3 (1974) 23.

38. Paul, J, Gilmour, R S, Affara, N, Birnie, G, Harrison, P, Hell, A, Humphries, S, Windass, J \& Young, B, Cold Spring Harbor symposia quant biol 38 (1974) 885.

39. Ross, J, Ikawa, Y \& Leder, P, Proc natl acad sci US 69 (1972) 3620.

40. Aviv, H, Voloch, Z, Bastos, R \& Levy, S, Cell 8 (1976) 495

Rcceived June 22, 1977

Revised version received August 8, 1977

Accepted August 12, 1977 